University of Michigan Law School

University of Michigan Law School Scholarship Repository

\title{
Medical Marijuana, Taxation, and Internal Revenue Code Section $280 \mathrm{E}$
}

Douglas A. Kahn

University of Michigan Law School, dougkahn@umich.edu

Howard J. Bromberg

University of Michigan Law School, hbromber@umich.edu

Available at: https://repository.law.umich.edu/articles/2320

Follow this and additional works at: https://repository.law.umich.edu/articles

Part of the Criminal Law Commons, Food and Drug Law Commons, Health Law and Policy Commons, and the Tax Law Commons

\section{Recommended Citation}

Kahn, Douglas A. and Howard Bromberg. "Medical Marijuana, Taxation, and Internal Revenue Code Section 280E." National Tax Journal 73, no. 2 (2020): 593-616. DOI: https://doi.org/10.17310/

ntj.2020.2.09

This Article is brought to you for free and open access by the Faculty Scholarship at University of Michigan Law School Scholarship Repository. It has been accepted for inclusion in Articles by an authorized administrator of University of Michigan Law School Scholarship Repository. For more information, please contact mlaw.repository@umich.edu. 


\title{
MEDICAL MARIJUANA, TAXATION, AND INTERNAL REVENUE CODE SECTION 280E
}

\author{
Douglas A. Kahn and Howard Bromberg
}

\begin{abstract}
Congress enacted $\$ 280$ E of the Internal Revenue Code in 1982 to punish businesses engaged in illegal drug trafficking, including marijuana. Section $280 E$ denies all credits and deductions, including ordinary business expenses, from gross income of businesses illegally trafficking in a Schedule I or II controlled substance. This provision violates the principle that the tax code should foster a consistent treatment of income, regardless of source; and that the income tax is ill-used for punitive measures. Now that marijuana has been legalized in some form in at least 46 states for therapeutic purposes, this federal tax penalty transgresses principles offederalism. Recent scientific studies that have established the medical effectiveness of marijuana for certain conditions, further demonstrates that $\$ 280$ E serves little legitimate purpose.
\end{abstract}

Keywords: marijuana taxation, drug law, business deductions

JEL Codes: I12, K32, K42, L65

\section{INTRODUCTION}

$t$ would seem difficult to assess federal tax policy on marijuana without an accurate assessment of its health effects. Public perceptions of marijuana over the last century have been dramatically transformed: from a public heath scourge and an imminent threat to society to an herbal medicine with a range of health benefits. Federal law as to marijuana was crystalized in its darkest days: the classification of marijuana in Schedule I of the Controlled Substances Act (CSA) in 1970 and the enactment of $\S 280 \mathrm{E}$ of the Internal Revenue Code in 1982. As a Schedule I drug under the CSA, use of marijuana is essentially prohibited under federal law, subject to severe penalties; under $\S 280 \mathrm{E}$, marijuana businesses are denied all credits and deductions, including ordinary business expenses, from gross income. Now that marijuana is perceived by the majority of the public as a potential medicine with significant health benefits and tolerable side effects, ${ }^{1}$

\footnotetext{
1 https://www.pewresearch.org/fact-tank/2019/11/14/americans-support-marijuana-legalization/.
}

Douglas A. Kahn: The University of Michigan Law School, Ann Arbor, MI, USA (dougkahn@umich.edu) Howard Bromberg: The University of Michigan Law School, Ann Arbor, MI, USA (hbromber@umich.edu) 
like many drugs on Schedules II-V, the majority of states have legalized marijuana use for health reasons, and 11 states have legalized it for adult recreational use as well. If non-intoxicating Cannabidiol (CBD), a chemical compound of the marijuana plant, is included, almost every state can be considered to have legalized marijuana, at least for medicinal purposes. Nevertheless, federal marijuana tax policy is essentially unchanged. The prohibition of deductions for marijuana under $\S 280 \mathrm{E}$ is directly linked to its Schedule I status, which is based on a medical assessment of the health effects of cannabis. ${ }^{2}$ Section II of this article examines the current state of evidence as to the health effects of marijuana to see if the tax code's animus to its use can be sustained. As Section II finds that medical evidence indicates that marijuana is not a dangerous narcotic, Section III indicates what would be a more rational tax policy, especially as regards $\S 280 \mathrm{E}$, and states the authors' beliefs that the tax code should focus on a consistent treatment of income, regardless of source, and not attempt to supplement the criminal law. Section IV examines recent proposals to amend $\S 280 \mathrm{E}$ or mitigate its effect on the marijuana business in light of the evidence of marijuana's health benefits.

\section{MEDICAL EVIDENCE AS TO MARIJUANA AND TAX LAW}

Few drugs have undergone the dramatic change in public perception of health risks and benefits as has marijuana over the last century. When marijuana emerged into public consciousness in the 1930s and 1940s, it was demonized, often in racial terms directed against Mexican immigrants. ${ }^{3}$ A rash of books and movies, such as the notorious exploitation film Reefer Madness, portrayed marijuana as a destroyer of the lives of the nation's youth. This opprobrium grew with the embrace of marijuana by beat poets in the 1950s and by hippies and anti-war activists in the 1960s. In the War on Drugs and Just Say No initiatives of the federal government in the succeeding decades, pot was often described as public enemy number one. When marijuana was scheduled on the CSA, it was in the midst of the federal government's campaign to warn of its dangerous health effects; marijuana was placed on Schedule I, the most restricted and penalized schedule of the CSA, despite the recommendation of the Shafer Commission. ${ }^{4}$

As detailed in Section III, in the midst of this anti-marijuana animus was enacted one of the more restrictive provisions of the income tax code $-\S 280 \mathrm{E}$ of the Internal Revenue Code. Nevertheless, public perception changed dramatically in the 1990s, manifested by California in 1996 when, by popular referendum, medical marijuana was legalized. By 2019, 33 states had legalized medical marijuana; 11 of those states legalized adult

2 Marijuana is controlled in Schedule I because it is determined that (1) it has a high potential for abuse, (2) it has no currently accepted medical use in treatment in the United States, and (3) there is a lack of accepted safety for its use under medical supervision. 21 U.S.C. $\S 812(b)(1)$.

3 Mosher, Clayton J., and Scott Akin, 2019. In the Weeds: Demonization, Legalization, and the Evolution of U.S. Marijuana Policy. Temple University Press, Philadelphia, PA.

4 Dufton, Emily, 2017. Grass Roots: The Rise and Fall and Rise of Marijuana in America, 52-56. Hachette Book Group, New York, NY. The Shafer Commission, established under the CSA as the National Commission on Marihuana and Drug Abuse, found that marijuana was not a dangerous drug. 
recreational marijuana as well. An additional 13 states legalized CBD. According to a 2019 Gallup poll, 66 percent of Americans favored legalizing marijuana, as compared to 31 percent in 2000, 28 percent in 1977, and 12 percent in 1969.

What does medical and scientific evidence say about the health effects of marijuana? Although studies of marijuana have been restricted due to federal law, sufficient evidence has been gathered from domestic and international studies over the last two decades, as well as an abundance of anecdotal and historical evidence, to reach certain conclusions.

\section{A. National Academies of Sciences, Engineering, and Medicine Medical Study}

The most comprehensive study of the medical evidence as to marijuana was published by the National Academies of Sciences, Engineering, and Medicine (NASEM) in 2017. ${ }^{5}$ This study incorporated over 10,000 domestic and international scientific papers. The results of this study found marijuana to be a drug that provides a therapeutic effect for certain conditions while presenting tolerable risks. For example, the study found strong evidence that cannabis and cannabinoids were effective as an analgesic for treating chronic pain in adults, resulting in a significant reduction in pain symptoms. The study also found cannabis and cannabinoids effective as antiemetics in reducing nausea and vomiting resulting from chemotherapy. Likewise, cannabis was effective in increasing appetite and decreasing weight loss associated with HIV/AIDS. Cannabis can reduce spasticity symptoms for multiple sclerosis and has been shown to help sleep outcomes for individuals with sleep disturbance associated with certain diseases. Cannabis may be effective for improving symptoms of post-traumatic stress disorder, of social anxiety disorder, and of disability after a traumatic brain injury. The study indicated that cannabis has some ability to improve symptoms of Tourette syndrome. A predecessor 1999 comprehensive study by the NASEM found that although some chronic users can develop dependence on marijuana, withdrawal symptoms are relatively mild and short-lived.

Health risks of cannabis and cannabinoids were certainly confirmed but were not beyond those tolerated for many medicinal drugs. The NASEM study found that longterm smoking of cannabis could aggravate respiratory symptoms, including cough and phlegm production, and bronchitis episodes. Cannabis smoking by gravid women can result in lower birth weight of offspring. The study found an association of cannabis use with one sub-type of testicular cancer. Among the most frequent cannabis users, there could be risk of developing schizophrenia or other psychoses. For adolescent users, there are possible links to anti-motivational syndrome (apathy to effort-related decision-making and reward-learning). Most concerning were various findings that show

\footnotetext{
National Academies of Sciences, Engineering, and Medicine; Health Medicine Division; Board on Population Health Public Health Practice; Committee on the Health Effects of Marijuana: An Evidence Review and Research Agenda, 2017. The Health Effects of Cannabis and Cannabinoids: The Current State of Evidence and Recommendations for Research. The National Academies Press, Washington, DC, https:// www.nap.edu/catalog/24625/the-health-effects-of-cannabis-and-cannabinoids-the-current-state.
} 
that acute marijuana use by adolescents could impair cognitive domains of learning, memory, and attention.

As to the controversial issue of whether marijuana is a "gateway drug," leading to use of more dangerous narcotics, studies are inconclusive. As noted in a comprehensive National Institute of Justice Study in 2018, neither the NASEM nor the National Institute of Justice were able to claim a causal link between cannabis use and the use of other illicit drugs, with the current studies available. ${ }^{6}$

After the release of the NASEM Report, new evidence of marijuana's effectiveness in treating epileptic symptoms was published. In 2018, clinical studies by pharmaceutical companies established the effectiveness of marijuana for refractory seizures. As a result, on June 25, 2018, the Food and Drug Administration (FDA) gave its first approval to a drug containing a marijuana extract: Epidiolex. In September 2018, the Drug Enforcement Administration (DEA) classified Epidiolex in Schedule V, the first marijuana extract of the cannabis plant to be placed in a less stringent schedule than Schedule I. ${ }^{7}$ Epidiolex is an oral-based treatment for Lennox-Gastaut syndrome and Dravet syndrome, two rare forms of pediatric epilepsy.

Before the approval of Epidiolex, the FDA and DEA had already approved several synthetic cannabinoids for various medical treatments. Marinol, a synthetic form of dronabinol, was classified as a Schedule III substance in 1999. Two other synthetic cannabinoids, Syndros and Nabilone (trade name Cesamet), are Schedule II drugs. Nabiximols (trade name Sativex) is an ethanol cannabis extract that is licensed overseas in 29 countries, including Canada, Spain, and the United Kingdom, and is undergoing advanced clinical trials for FDA approval. In addition, the U.S. Department of Health and Human Services (HHS) itself holds Patent no. 6,630,507, which covers cannabinoids as antioxidants treating a wide variety of oxidation-related diseases and as neuroprotectants treating neurological damage and neurodegenerative diseases. ${ }^{8}$ Despite the availability of these FDA-approved products, there is good evidence that whole plant cannabis, still prohibited under federal law, provides more effective therapeutic benefit due to the "entourage effect," in which botanical compounds work synergistically to enhance benefits and reduce side effects. ${ }^{9}$

As such, there is accumulated evidence that marijuana provides certain health benefits. The risk of side effects should not be underestimated but appears comparable to that of many drugs approved by the FDA. ${ }^{10}$

\footnotetext{
${ }^{6}$ Noel, William, and Judy Wang, 2018. Is Cannabis a Gateway Drug? Key Findings and Literature Review, 11. Department of Justice, The National Institute of Justice, Washington, DC, https://www.ncjrs.gov/pdffiles $1 /$ nij/252950.pdf.

${ }^{7}$ Schedules of Controlled Substances: Placement in Schedule V of Certain FDA-Approved Drugs Containing Cannabidiol, 2018. 83 Fed. Reg. 48950.

${ }^{8} \mathrm{https} / /$ upload.wikimedia.org/wikipedia/commons/f/f0/US-patent-6630507.pdf.

${ }_{9}^{9}$ McPartland, John M., and Ethan B. Russo, 2001. "Cannabis and Cannabis Extracts: Greater Than the Sum of Their Parts?" Journal of Cannabis Therapeutics 1 (3-4), 103-132.

${ }^{10}$ Boehnke, Kevin, Evangelos Litinas, and Daniel Clauw, 2016. "Medical Cannabis Use Is Associated with Decreased Opiate Medication Use in a Retrospective Cross-Sectional Survey of Patients with Chronic Pain.” The Journal of Pain 17 (6), 739-744; Corroon Jr., James, Laurie K Mischley, and Michelle Sexton, 2017. "Cannabis as a Substitute for Prescription Drugs - a Cross-Sectional Study." Journal of Pain Research 10, 989-998.
} 


\section{B. FDA Review}

On August 12, 2016, the DEA rejected the latest filed petition to reschedule marijuana under the CSA, reaffirming its decision that (1) marijuana has a high potential for abuse, (2) it has no currently accepted medical use in treatment, and (3) there is a lack of accepted safety practices for its use under medical supervision. ${ }^{11}$ The DEA based its conclusions, in large part, on two comprehensive reviews of medical evidence undertaken by both the HHS (June 25, 2015) 12 $^{12}$ and the FDA (March 19, 2015). ${ }^{13}$ However, it is noteworthy that significant points made in both of these reviews are in accord with the NASEM 2017 study. For example, the FDA evaluation, based on 11 clinical studies from 1974 to 2013, found evidence that marijuana "effectively reduced chronic neuropathic pain from HIV-associated sensory neuropathy," "increase[s] caloric intake and produce[s] weight gain in HIV-positive patients," has "usefulness in reducing pain and spasticity associated with MS [Multiple Sclerosis]," and produced improvements in analgesia for patients with chronic neuropathic pain and bronchodilation for those with clinically stable asthma. Significantly, the FDA found that cognitive impairments produced by marijuana are mild and withdrawal symptoms from marijuana use are similar to those caused by nicotine. The FDA noted both the euphoric and dysphoric effects induced by the intoxicating effects of tetrahydrocannabinol (THC). Marijuana was also found by HHS not to be an immediate precursor of use of another controlled substance (not a "gateway drug"). ${ }^{14}$

Although the DEA recognized this positive evidence on health, its decision to deny rescheduling was as much a legal decision as a medical one, finding that the "only determinative issue in evaluating the present scheduling petition is whether marijuana has a currently accepted medical use in treatment in the United States." 15 Because the DEA determined that no published studies met the legal criteria "for an adequate and well-controlled study for purposes of determining the safety and efficacy of a human drug," it could not find a "currently accepted medical use in treatment in the United States," despite the evidence reviewed by the FDA and other

11 U.S. Department of Justice, Drug Enforcement Administration, 2016. Marijuana Scheduling Petition; Denial of Petition of Governors Lincoln Chafee and Christine O. Gregoire to Initiate Proceedings to Reschedule Marijuana. 81 Fed. Reg. 53,688 and 53,739; Marijuana Scheduling Petition; Denial of Petition of Bryan A. Krumm to Initiate Proceedings to Reschedule Marijuana. 81 Fed. Reg. 53,767 and 53,820, https://www. govinfo.gov/content/pkg/FR-2016-08-12/pdf/2016-17954.pdf.

${ }^{12}$ U.S. Department of Health and Human Services, 2015. Basis for the Recommendation for Maintaining Marijuana in Schedule I of the Controlled Substances Act. 81 Fed. Reg. 53,690; 53,769, https://www. govinfo.gov/content/pkg/FR-2016-08-12/pdf/2016-17954.pdf.

${ }^{13}$ U.S. Food and Drug Administration, 2015. The Medical Application of Marijuana: A Review of Published Clinical Studies Prepared by: U.S. Food and Drug Administration. 81 Fed. Reg. at 53,712; 53,791, https:// www.govinfo.gov/content/pkg/FR-2016-08-12/pdf/2016-17954.pdf.

${ }^{14}$ U.S. Department of Health and Human Services, 2015. Basis for the Recommendation for Maintaining Marijuana in Schedule I of the Controlled Substances Act. 81 Fed. Reg. 53,705; 53,784.

${ }^{15}$ The DEA uses a five-part test to determine whether a drug has a "currently accepted medical use": (1) the drug's chemistry must be known and reproducible, (2) there must be adequate safety studies, (3) there must be adequate and well-controlled studies proving efficacy, (4) the drug must be accepted by qualified experts, and (5) the scientific evidence must be widely available. See 57 Fed. Reg. at 10,506; Alliance for Cannabis Therapeutics v. DEA, 15 F.3d 1131, 1135 (D.C. Cir. 1994). 
researchers. ${ }^{16}$ Given the federal restrictions on marijuana use and research, finding a "currently accepted medical use in treatment in the United States" would be next to impossible under DEA criteria. ${ }^{17}$

Some of the implications of the current evidence of the health effects of marijuana use on federal taxation of its use, and in particular on $\S 280 \mathrm{E}$ as to marijuana sellers, are presented in the Section III. The evidence that marijuana is not a dangerous narcotic, and has certain health benefits, supports the authors' assertions that tax policy in this area should be based on standard principles of taxing income, regardless of source, and not an effort to use the income tax code to manipulate social behavior. Cigarette taxation, alcohol taxation, and the like are excise taxes; use of the income tax, even if taxation were warranted, would make an inadequate substitute.

\section{INCOME TAX TREATMENT OF MARIJUANA BUSINESS}

While a growing number of states have made it legal to obtain marijuana, especially for medical purposes, Congress has yet to join that trend. As described in Section II, the federal government has long shown considerable concern as to the use of drugs (in a way, especially marijuana) and the adverse consequences of their use on health and on life itself. One measure adopted by Congress to address that problem was a tax provision ( $\left(280 \mathrm{E}\right.$ ) that was added to the Internal Revenue Code in $1982 .{ }^{18}$ Section $280 \mathrm{E}$ denies a tax deduction or credit to any expense incurred in carrying on a trade or business of trafficking in a controlled substance within the meaning of Schedules I and II of the CSA. ${ }^{19}$ Marijuana is included in Schedule I of that Act, so any expense incurred in the

${ }^{16}$ The criteria "for an adequate and well-controlled study for purposes of determining the safety and efficacy of a human drug" are defined under the Code of Federal Regulations (CFR) in 21 CFR 314.126. These criteria include strictly controlled and comprehensive clinical trials so that the FDA can perform "extensive risk-benefit analysis to determine whether the risks posed by the drug product's side effects are outweighed by the drug product's potential benefits for a particular indication." Although the 11 clinical studies of marijuana evaluated by the FDA were randomized controlled trials that were placebo-controlled and double-blinded, they did not meet DEA criteria for "an adequate and well-controlled study." Thus, the FDA classified them as "proof of concept" studies.

${ }^{17}$ For example, Quattrone, Elena M., 2016. "The 'Catch-22' of Marijuana [Il]Legalization.” Boston University Journal of Science \& Technology Law 22 (2), 299-325; Eisenberg, Rebecca, and Deborah Leiderman, 2019. "Cannabis for Medical Use: FDA and DEA Regulation in the Hall of Mirrors." Food \& Drug Law Journal 74 (2), 261-268; O’Connor, Sean, and Erika Lietzan, 2019. "The Surprising Reach of FDA Regulation of Cannabis, Even after Descheduling." American University Law Review 68 (3), 858-885.

${ }^{18}$ Section 351(a) of the Tax Equity and Fiscal Responsibility Act of 1982, P.L. 97-248, 96 Stat. 324 (1982). The stimulus for adopting that provision was a 1981 Tax Court case in which the court allowed a deduction for lawful expenses of an illegal drug business. Edmondson v. Commissioner, 42 T.C.M. (CCH) 1533 (1981). Congress was unhappy with that result.

19 "No deduction or credit shall be allowed for any amount paid or incurred during the taxable year in carrying on any trade or business if such trade or business (or the activities which comprise such trade or business) consists of trafficking in controlled substances (within the meaning of schedule I and II of the Controlled Substances Act) which is prohibited by Federal law or the law of any State in which such trade or business is conducted." This language is unchanged from its original enactment in 1982. 
marijuana business is not deductible regardless of whether the business is lawful under state law. The purpose of adopting this provision is stated in the following quotation from the Report of the Senate Finance Committee:

There is a sharply defined public policy against drug dealing. To allow drug dealers the benefit of a business expense deduction at the time that the U.S. and its citizens are losing billions of dollars per year to such persons is not compelled by the fact that such expenses are allowed to other legal enterprises. Such deductions should be disallowed on public policy grounds. ${ }^{20}$

The ordinary legal expenses of a business are deductible even if the business is unlawful. ${ }^{21}$ Section $280 \mathrm{E}$ creates an exception to that rule and bars a deduction for the lawful expenses of certain drug businesses even when the business itself is lawful under state law. The ordinary expenses of a business typically are deductible so that only net income is taxed. If no deduction were allowed for business expenses, those businesses with higher expenses would be subject to greater taxation than businesses with lower expenses, holding fixed revenues. A denial of a deduction for ordinary expenses means that those taxpayers are taxed on gross income. Gross income is the difference between the amount realized by a taxpayer and the cost of goods sold. No reduction is made for expenses. Section 280E's denial of a deduction for ordinary expenses of a marijuana business makes that business taxed on its gross income while all other non-drug businesses, even unlawful ones, are taxed on net income. It is the view of the authors that the denial of a deduction for the lawful expenses of a marijuana business, whether or not the business is lawful, is a punitive provision that is inappropriate and should be repealed.

As noted above, an unlawful business can deduct its lawful expenses. ${ }^{22}$ The Internal Revenue Service has stated, for example, that a seller of illegal arms is allowed to deduct commissions paid to transact sales. ${ }^{23}$ In fact, courts have allowed business deductions for taxpayers engaged in illegal gambling, illegal lottery operations, illegal prostitution, racketeering, and general organized crime ${ }^{24}$ It is only a drug business that is prohibited from deducting its legal expenses, and that prohibition applies even when the drug business is legal under state law. Congress may consider the drug business a greater problem than other illegal activities, but there still is a question if that discriminatory tax treatment is justified. Moreover, in contrast to other illegal drugs, whatever problem there might be with the dissemination of marijuana, it is unlikely to be more egregious than the consequences of many other unlawful activities such as illegal arms sales and organized

\footnotetext{
${ }^{20}$ S. Rept. No. 97-494, vol. 1, at 309.

${ }^{21}$ See Accardo v. United States, 942 F2d 444 (7th Cir. 1991).

${ }^{22}$ See Accardo, n. 21, supra.

${ }^{23}$ F.S.A. 2001-28-004 (July 13, 2001).

${ }^{24}$ Roche Jr., Edward, 2013. "Federal Income Taxation of Medical Marijuana Businesses." Tax Lawyer 66 (2), 434; Pack, Julie, 2017. "Powerless to Penalize: Why Congress Lacks the Power to Penalize Marijuana Businesses through § 280E of the Internal Revenue Code.” Arizona Law Review 59 (4), 1086-1087.
} 
criminal activity resulting in murder. That is especially true since the overwhelming number of states have decided that marijuana has potential health benefits, and have legalized it (or its constituent CBD) for medical use, and 11 states - including some of our most populous - have decided that marijuana presents tolerable risks and have legalized it for adult recreational purposes. ${ }^{25}$ The federal tax is especially questionable since the legislative history of $\S 280 \mathrm{E}$ shows that it was not added to the Code for revenue enhancement but rather was added as a punitive measure. Even if the tax is seen as a means of collecting revenue on a product that also has social costs, as is the case with cigarette taxes, an excise tax would better serve that purpose than using the income tax.

Current tax law denies a deduction for illegal expenses regardless of whether the business is a lawful one. ${ }^{26}$ In a prior article, the authors discussed that treatment and concluded that it imposed arbitrary penalties and should be repealed. ${ }^{27}$ There should be some correlation between the severity of a penalty and the seriousness of the crime; the penalty on a marijuana business depends upon an item (costs incurred) that is neither the harm to be taxed nor is correlated with that harm. The degree of punishment caused by a denial of a deduction for an expense that produces income has no relationship to the nature of the offense and so is an arbitrary policy. But the treatment of a marijuana business by $\S 280 \mathrm{E}$ goes even further by denying a deduction for ordinary lawful expenses of a lawful business. Let us consider what justifications there might be for this provision and whether they can stand scrutiny.

\section{A. Sin Tax}

One possible justification for the denial of a deduction is that raising the tax costs of the dealer or producer will raise the cost of acquiring marijuana and, thereby, decrease the demand for it and reduce the amount of its use. In other words, the provision can be viewed as a kind of sin tax. The quotation above from the Senate Finance Report gives reason to doubt that was the Congressional purpose for the adoption of the provision, but nevertheless can it be defended on that ground?

First, there is no reason to impose a sin tax on the medical use of marijuana. The use of medicine to relieve pain is not against public policy, and there is no reason to increase the cost of obtaining that relief. Indeed, increasing the cost would be contrary to the public policy of having medicine affordable to those who need it. At the very least, if the denial of a deduction were a sin tax, a distinction should be made between a purchase for medicinal use and a purchase for recreational use. ${ }^{28}$ The question would

${ }^{25}$ For a listing of which states have legalized marijuana and for which purposes, see "Appendix, Marijuana Law by Jurisdiction.” In Bromberg, Howard, Mark Osbeck, and Mike Vitiello, 2019. Cases and Materials on Marijuana Law, 687-692. West Academic Publishing, St. Paul, MN.

${ }^{26}$ Section 162(c) of the Internal Revenue Code of 1986.

${ }^{27}$ Kahn, Douglas, and Howard Bromberg, 2016. "Provisions Denying a Deduction for Illegal Expenses and Expenses of an Illegal Business Should Be Repealed." Florida Tax Review 18 (5), 233-234.

${ }^{28}$ In states that legalized marijuana for both medical and adult recreational purposes, purchase of marijuana pursuant to a medical registration card or license is taxed at a lower rate. 
be whether that distinction can be made in practice. The taxpayer could be required to show that the marijuana produced was held only for sale for medicinal purposes. If that requirement were made, marijuana dealers and producers would segregate the inventory dedicated to medicinal use from the rest of their inventory so that only the latter would be taxed. With the vast majority of states legalizing some form of marijuana for medical purposes, and even the DEA and FDA certifying that it has at least some medical benefits, it is worth noting that no other product or activity that has proven health benefits is subject to a sin tax.

Even if that distinction were adopted, the imposition of a sin tax on recreational marijuana is questionable. In states where marijuana is legal, it is expensive to purchase it legally. It is probable that the tax law's denial of a deduction is a factor in the high costs. ${ }^{29}$ Consequently, a black market has arisen that sells marijuana for much less than the lawful market. The deduction denial (which for this discussion we are treating as a sin tax) has the side effect of creating an incentive for a black market in which the dealers do not report and pay taxes. One negative of having a black market is that the government cannot regulate the production of the product to ensure that there are no harmful impurities in it.

Sin taxes typically are excise taxes. There is no other situation in which a sin tax is imposed through the income tax system. There are good reasons not to use the income tax as a means of imposing a sin tax. The denial of a deduction contravenes the goals of horizontal and vertical equity. Horizontal equity means taxing persons the same who have the same income. Vertical equity means that persons having disparate incomes pay a tax that bears a reasonable relationship to the disparity in their incomes. Concededly, those goals are violated by some provisions of the tax law, but, at a minimum, such departures should not operate arbitrarily.

The denial of a deduction - deemed to be a sin tax — does operate arbitrarily. The amount of the tax depends upon the amount of lawful expenses incurred. A dealer who operates in a jurisdiction in which costs are high will bear a greater effective tax rate $^{30}$ than a dealer who earns the same gross income but operates in a jurisdiction with

${ }^{29}$ Even where taxes of marijuana are high, such as in Washington where they average 37 percent, the denial of a deduction for wages, rent, and other expenses will be a substantial dollar amount and will raise the cost of marketing the drug. It is not state taxation alone that raises the selling price but also the costs of the deduction denial. As far as the dealer is concerned, his costs are the expenses he incurs and any excise taxes he has to pay on that item. An additional income tax for denying a deduction for wages and other expenses raises the cost of incurring those expenses and so can be seen as an additional cost just as the excise tax is an additional cost. As far as the dealer is concerned, an excise tax is just one of the costs he incurs to market his product. It is the total amount of those costs that affects the selling price, and one cannot say that one of those costs has a greater influence on price than another one does. Since the denial of a deduction is a significant cost, it contributes to the size of his total costs and, thereby, affects the selling price of the item. Adding another cost to the current ones could affect the selling price of the product, but it would be the increase in the total cost that did so and not the identity of the newly added cost.

${ }^{30}$ Effective tax rate is the percentage of taxpayer's net income represented by the amount of the taxpayer's tax liability. 
lower costs. ${ }^{31}$ Paradoxically, a dealer selling marijuana in a high cost jurisdiction can pay a higher tax than a dealer who sells more marijuana in a low cost jurisdiction. This contravenes the purpose of a sin tax to reduce the consumption of the item. Given that the $\sin$ in question is the distribution of marijuana and the tax is designed to reduce that distribution, it makes little sense to have the tax operate in such manner that it is possible for a dealer who sells more marijuana than another to incur a lower tax than the one who sells a lesser amount. Low costs are not necessarily due to greater efficiency. For example, the cost of labor is higher in some jurisdictions than in others. Since income tax rates of individuals are graduated, putting an individual taxpayer (including individual partners or members of a business conducted by a partnership or limited liability company (LLC)) in a higher tax bracket because of the denial of a deduction exacerbates the arbitrariness of the imposition. If an excise tax were imposed at a flat rate on the weight of the item, there would be a greater equality of treatment and it would be better suited to reducing the consumption of the item. Even if an excise tax were imposed on the selling price of the marijuana instead of by weight, it would be at a flat rate and would not have the added disparity of treatment that a graduated income tax system imposes. In other words, a flat tax on weight is dependent upon the amount of marijuana sold, which would be the aim of a sin tax. In contrast, the current tax does not correlate with the amount of marijuana that is sold. Actually, the tax is not on the revenue received but rather on the amount of lawful expenses incurred, and that is even less effective because the costs incurred are even less correlated to the amount marketed. Consider the following illustrations.

Ex. 1. X (an unmarried individual) operates a lawful marijuana business in the state of Nadia. In Year One, $\mathrm{X}$ has gross receipts from the sale of marijuana of $\$ 800,000$ and cost of goods sold of $\$ 200,000 \cdot .^{32} \mathrm{X}$ has ordinary lawful business expenses of $\$ 250,000$. While $X$ has net income of $\$ 350,000$, $X$ will be taxed on his gross income of $\$ 600,000$. X will pay a federal income tax of $\$ 187,689$ on that $\$ 600,000$ of gross income.

$\mathrm{Y}$ (an unmarried individual) operates a lawful marijuana business in the state of Garnia. In Year One, Y has gross receipts of $\$ 900,000$ for selling more marijuana than $X$ sold that year. $Y$ has cost of goods sold of $\$ 300,000$, so his gross income is $\$ 600,000$. Y also has ordinary lawful expenses of $\$ 100,000$. Y's net income is $\$ 500,000$. Although Y's net income is $\$ 150,000$ greater than $X$ 's, and although Y sold more marijuana than X, Y pays the same federal income tax as $\mathrm{X}$.

31 At the state level, marijuana may be subject to sales tax, excise tax, licensing fees, and the like, with varying bases for taxes, where on the seedling-to-sale chain to apply the taxes, and from whom to collect the taxes - producers, distributors, or customers. Marijuana can be taxed according to weight or price; by potency, usually calculated by the quantity of THC; by square footage of growing space; or even by an electrical add-on tax that calculates the use of electricity in a home beyond normal use (excess electricity as a proxy for indoor lighting for marijuana plants). In states that legalized adult recreational use marijuana, medical marijuana is taxed at a lower rate.

32 As noted later in this article, drug businesses are permitted to reduce gross receipts by the cost of goods sold. See S. Rept. No. 97-494, vol. 1, at 309. 
This example shows that even without regard to the effect of graduated taxation, the denial of a deduction operates perversely so that $\mathrm{Y}$, who has sold more marijuana than $\mathrm{X}$ and has greater net income and gross receipts, nevertheless pays the same federal income tax as $\mathrm{X}$.

Ex. 2. G (an unmarried individual) operates a lawful marijuana business in the state of Erehwon. In Year One, G has gross receipts from the sale of marijuana of $\$ 1,100,000$ and cost of goods sold of $\$ 500,000$. G's gross income is $\$ 600,000$. $\mathrm{G}$ has lawful business expenses of $\$ 400,000$. While $\mathrm{G}$ has a net income of only $\$ 200,000$, he will be taxed on his gross income of $\$ 600,000$ since no deduction is allowable for his expenses. $G$ will pay a federal income tax of $\$ 187,689$.

Y (an unmarried individual) operates a lawful marijuana business in the state of Nirvana. In Year One, Y sells more marijuana than G did and has gross receipts of $\$ 1,200,000$ from those sales. Y's cost of goods sold is $\$ 750,000$, so his gross income is $\$ 450,000$. Y has ordinary lawful expenses of $\$ 100,000$. Y's taxable income will equal his gross income of $\$ 450,000$, and $\mathrm{Y}$ will pay a federal income tax of $\$ 133,189$. Y's net income was $\$ 350,000$, but $Y$ is not allowed a deduction for his $\$ 100,000$ of expenses. Although $Y$ sold more marijuana than $\mathrm{G}$, and although Y had a net income of $\$ 150,000$ more than G, Y's federal income tax is $\$ 54,500$ less than the tax that $G$ pays $(\$ 187,689-\$ 133,189)$. The discrepancy is exacerbated by the fact that the marginal tax rate applicable to $\mathrm{G}$ is 37 percent, whereas the marginal tax rate applied to $\mathrm{Y}$ is only 35 percent.

Another consideration for not using the income tax law as a means of deterring behavior is that there is a meaningful administrative cost to loading the income tax with non-income-tax related incentives or disincentives. This added administrative burden has an adverse effect on taxpayer compliance..$^{33}$

\section{B. Punitive}

The denial of a deduction can be seen as a punitive measure to punish persons dealing in an industry of which Congress disapproves. There are three objections to that proposed justification.

\footnotetext{
${ }^{33}$ The Internal Revenue Code is a large and complex document that is difficult even for experts to navigate much less laymen. Every addition to that Code creates additional complexity and increases the difficulty of dealing with the subject. This is especially true when the addition constitutes exceptions to existing provisions so that the taxpayer and the government agents have to work their way through the circumstances when a provision applies and when it does not. This increases the difficulty for taxpayers and increases their frustration. It also makes it more difficult for the government agents who have to administer the tax laws. Former U.S. Commissioner of Internal Revenue Service Mortimer M. Caplin urged that the Code not be burdened with provisions not designed for the better measurement of net income but rather to implement some other agenda. "We also see the tax laws excessively used, again and again, to promote a wide variety of social and economic objectives. The result: tax base erosion, shifting of the tax burden, added complexities, and further fueling of taxpayer frustration." "Simplification of the Tax System," 2004. U.S. House of Representatives, Hearing Subcommittee on Oversight of the Committee on Ways and Means, Washington, DC.
} 
One of the objections is the same as the one described above for a sin tax justification. Namely, the amount of the punitive measure is determined by the amount of expenses incurred, and that has no relationship to the degree of the offense. The punitive provision applies arbitrarily. It is unacceptable to have the degree of punishment rest on arbitrary elements. For example, if a punitive provision were to make the amount of fine depend upon whether it was raining when the sentence was imposed, that would be unacceptable. If the punishment were scaled to the height of the offender, that would also be unacceptable. The amount of punishment should bear a reasonable relationship to the seriousness of the offense and not rest on grounds that have nothing to do with how heinous the offense might be. If the denial of the deduction for ordinary expenses is deemed a punitive provision, it fails to satisfy the condition that it be reasonably related to the seriousness of the offense..$^{34}$

A second objection is also one that is discussed above in connection with the sin tax. Whatever justification there might be for penalizing the marketing of marijuana for recreational purposes, there is little for penalizing the marketing of it for medicinal purposes. It is contrary to public policy to deter providing relief to patients who have a medical condition. At the very least, there should be no denial of a deduction for marketing marijuana for medical use. The government should not impose an extra tax burden on acquiring medical care.

Another objection that relates to the marijuana industry is that there is a growing public sentiment that the use of marijuana should be lawful. ${ }^{35}$ It is contrary to the role of federalism to have the federal entity punish through the tax code something that a large number of states treat as lawful. One function of federalism is to allow the states to take different approaches to see how things turn out. The states are laboratories for experimentation. When the question of whether an item is harmful is subject to as much dispute as is the case with marijuana, the federal government should be alert to the experience of the states in deciding national marijuana policy. This consideration not only relates to repealing $\S 280 \mathrm{E}$, but also to which schedule to classify marijuana in the list of controlled substances, if it is to be included.

The federal government itself has been indecisive in its treatment of marijuana. In a series of memoranda promulgated by the Department of Justice (DOJ) in the period from 2009 to 2014, it announced that it would not enforce the CSA's prohibition against marijuana if certain conditions are met. ${ }^{36}$ As discussed later in this article, beginning in

${ }^{34}$ For further elaboration of that issue, see the article by Kahn and Bromberg, n. 27, supra.

35 Jones, Jeffrey, 2019 “U.S. Support for Legal Marijuana Steady in Past Year.” Gallup. https://news.gallup. com/poll/267698/support-legal-marijuana-steady-past-year.aspx

${ }^{36}$ In those memoranda, the Justice Department announced that it would not enforce the prohibition against marijuana in states that decriminalized its use as long as the states do not allow marijuana use that violates federal priorities. The memoranda list eight federal enforcement priorities to guide the states: (1) preventing distribution of marijuana to minors, (2) preventing revenue from sale of marijuana going to criminal enterprises, (3) preventing diversion of marijuana from states where it is legal to other states, (4) preventing marijuana activity from being used as a cover for trafficking of illegal drugs, (5) preventing violence and the use of firearms in marijuana activity, (6) preventing marijuana driving and other adverse public 
2014, Congress prohibited the DOJ from using funds to interfere with a state's legalization of marijuana. These two actions reflect the ambivalence regarding the question of whether the use of marijuana should be lawful.

\section{Revenue Measure}

Marijuana is a thriving business, so the government can raise substantial revenue by taxing it. Of course, it is appropriate to tax marijuana income to the same extent that other businesses are taxed. The denial of a deduction for lawful expenses is an additional tax on the approximately 5,000 legal marijuana companies, ${ }^{37}$ which in 2017 paid an estimated $\$ 4.7$ billion in federal taxes on nearly $\$ 13$ billion in revenue. Can that treatment be justified as just another revenue producing tax?

Congress has taxed different industries more favorably for economic reasons or for national security reasons. For example, the oil and gas industry was once allowed a large tax benefit in providing oil and gas businesses with a deduction for percentage depletion, and they still are granted some other tax benefits. The real estate industry is treated more favorably. ${ }^{38}$ It is one thing to tax one industry more favorably for policy goals and another to single out an industry for unfavorable tax treatment. The former is designed to encourage investment in an activity that is deemed important to social welfare or to national defense, whereas the latter is designed to reduce the accessibility of a product or activity that is deemed harmful. In either case, there should be valid reasons for encouraging or discouraging an activity and for using the tax law as the instrument to do so. In the latter case, when the tax is designed to restrain an activity, the case for doing so should be especially strong since the government is, thereby, censoring an activity that some of the public desires. If discriminatorily higher taxes are to be imposed, there should be a strong policy justification for doing so. The imposition of a higher tax because of disapproval of an industry should be treated as a punitive measure rather than a revenue raising measure. But, even if regarded as a revenue measure, there should be a policy justification for singling out that industry.

Whatever may be said about some other drug businesses, there is no policy justification for taxing marijuana businesses at a higher rate than other businesses. As noted

health consequences, (7) preventing growing of marijuana on public lands, and (8) preventing marijuana possession and use on federal property. As long as states have adequate measures to prevent those eight outcomes, the Justice Department indicates that it will not interfere with state legalization of marijuana. U.S. Department of Justice, Office of the Deputy Attorney General. Memorandum for all United States Attorneys: Guidance Regarding Marijuana Enforcement (Aug. 29, 2013), http://www.justice.gov/iso/ opa/resources/3052013829132756857467.pdf. Although Attorney General Jeff Sessions rescinded these memoranda on January 4, 2018 in a Memorandum for all United States Attorneys, this rescission has had no practical effect. As of this writing, the DOJ, to all intents and purposes, is operating under the guidelines set out in the Obama Administration memoranda.

${ }^{37}$ Mikos, Robert, forthcoming 2019. "The Evolving Federal Response to State Marijuana Reforms." Widener Law Review 25, 14-15. Available at SSRN: https://ssrn.com/abstract=3478299

${ }^{38}$ For example, see $\S 469(\mathrm{c})(7)$ and compare $\S 1250$ with $\S 1245$. 
above, there is considerable dispute as to whether marijuana should be prohibited and a number of states have chosen not to do so. Even heinous illegal businesses are permitted to deduct their lawful expenses. It is disputable as to whether the marijuana business is heinous at all, but certainly it is not as heinous as many illegal businesses that are permitted to deduct their lawful expenses.

It would seem that denying a deduction can have perverse consequences in that some persons producing and selling more marijuana can be taxed less than some persons who produce and sell less marijuana. Even if it were decided that an additional tax should be imposed on the marijuana business, the tax should be some form of an excise tax and not part of the income tax system. As noted above, the denial of an income tax deduction has perverse consequences that can be avoided by applying an excise tax instead.

\section{Advertising}

It has been suggested that one reason for the adoption of $\S 280 \mathrm{E}$ is that it raises the cost of advertising, as a non-deductible expense. ${ }^{39}$ It seems unlikely that was the Congressional purpose. It seems likely that advertising would take place only where the drug can be obtained legally. Illegal businesses are not likely to purchase advertising on television or in a local newspaper. It is hard to imagine that Opiates for Addicts would wish to advertise their business. The legislative history indicates that Congress was concerned primarily with more harmful drugs and that the advertising issue would apply almost exclusively to the marijuana business and then only in jurisdictions where it is legal to purchase it.

Even if one were to seek to restrain the advertising of marijuana in order to reduce its consumption, that should not apply to its medical use. As of now, the legality of marijuana advertising varies widely by state. As to federal law, under the CSA, 21 U.S.C. § 843(c) (1), marijuana advertising is explicitly illegal, although there may be some exception for medical marijuana advertising under the Rohrabacher-Farr Amendment. ${ }^{40}$ As noted in Section A, in discussing a proposed sin tax justification, there should be no restriction on advertising to show where marijuana can be obtained for medicinal purposes. It is true that if a jurisdiction allows recreational use of marijuana, a consequence of the advertisement of its availability for medicinal purposes would also inform the public where it can be obtained for recreational purposes. The policy of making drugs available to those who need them for medicinal reasons should override the concern for reducing recreational consumption, at least in the case of marijuana where certain health benefits outweigh the risks. The side effect of informing the public of availability, even if it leads to some abuse, is less significant than helping those in pain.

Another consideration is that, as noted previously, the question of whether the use of marijuana is unduly harmful is unclear. Not only have a number of states legalized its use, but the federal government has shown ambivalence about whether to outlaw it.

\footnotetext{
39 Jacobs, Leslie, 2017. "Regulating Marijuana Advertising and Marketing to Promote Public Health: Navigating the Constitutional Minefield Jacobs." Lewis \& Clark Law Review 21 (4), 1099-1100, n. 136.

${ }^{40}$ The Rohrabacher-Farr Amendment to the federal budget prohibits the DOJ from expending funds to enforce the federal prohibition in medical marijuana states. Consolidated Appropriations Act, 2018, Pub. L. No. 115-141, § 538, 132 Stat. 348, 444-445 (Mar. 23, 2018).
} 


\section{E. § 280E Provides an End Run to Criminal Procedure's Restrictions on the Government's Obtaining Evidence}

There is an additional objection to $\S 280 \mathrm{E}$ that applies to all of the proposed justifications for its retention. Since the enforcement of $\S 280 \mathrm{E}$ occurs in the context of civil litigation, the government can use subpoenas to obtain information that could not be obtained in a criminal prosecution. ${ }^{41}$ If the government subsequently decides to prosecute the operators of that business, they can use the information obtained from those subpoenas. Indeed, the government might well use $\S 280 \mathrm{E}$ as a means of obtaining that information before beginning the prosecution of a criminal case. Even apart from the question of marijuana consumption, this represents a small but possible threat to civil liberties.

\section{F. Cost of Goods Sold}

In adopting $\S 280 \mathrm{E}$, Congress made clear that the provision does not prevent the reduction of gross receipts by the cost of goods sold. ${ }^{42}$ This incentivizes dealers and producers of marijuana to try to characterize expenditures as capital expenditures (and so cost of goods sold) rather than as ordinary expenses. As a cost of goods sold, the taxpayers can use the expenditure to reduce their taxable income when the item is sold. In contrast, if the expenditure is characterized as an ordinary expense, it can never be used to reduce taxable income.

This causes a reversal of the normal litigating position of taxpayers and the government. Typically, taxpayers prefer to characterize an expenditure as an ordinary expense that is currently deductible, and the government typically seeks to characterize it as a capital expenditure. The treatment of the marijuana business changes that landscape.

\section{G. Medical Expense Deduction}

Section 213 of the Internal Revenue Code of 1986 allows a deduction for medical expenses subject to a floor. ${ }^{43}$ A medicine or drug (other than insulin) can qualify as a medical expense provided that it can be obtained only pursuant to a prescription of a doctor. ${ }^{44}$ The regulations provide that a medical expense is not deductible if it violates a federal or state law. ${ }^{45}$ While most prescribed medicines and drugs ${ }^{46}$ are deductible

\footnotetext{
${ }^{41}$ High Desert Relief, Inc. v. United States, No. 16-CV-816 (D. Ct. N.M. Mar. 31, 2017) (Memorandum Opinion and Order denying a petition to quash subpoenas and enforcing the subpoenas); Alpenglow Botanicals, L.L.C. v. United States, No. 16-CV-00258-RM-CBS, 2016 WL 7856477 (D. Colo. Dec. 1 2016); Temkin. Jeremy, 2019. "Incriminating Expenses: Cannabis: Legalization and the Fifth Amendment." New York Law Journal 262 (13), 3 https://www.maglaw.com/publications/articles/2019-07-18-incriminating-expensescannabis-legalization-and-the-fifth-amendment/_res/id=Attachments/index=0/070071916\%20Morvillo.pdf.

${ }^{42}$ S. Rept. No. 97-494, vol. 1, at 309.

${ }^{43}$ Generally, the medical expenses of an individual are deductible to the extent they exceed 10 percent of the individual's adjusted gross income. Section 213(a) of the Internal Revenue Code of 1986.

${ }^{44}$ Section 213(b) of the Internal Revenue Code of 1986.

${ }^{45}$ Treas. Reg. § 1.213-1(e)(1)(ii), (e)(2).

${ }^{46}$ Medicines or drugs that can be obtained without having a doctor's prescription do not qualify for the deduction even if a doctor does prescribe them.
} 
medical expenses, the regulations provide that the deduction is allowed only for items that are legally procured ${ }^{47}$ The Internal Revenue Service has ruled that the purchase of marijuana for medical purposes is not a legal procurement and so cannot be deducted. ${ }^{48}$

In one respect, the denial of a medical expense deduction might seem reasonable if one views the deduction as a kind of subsidy by the government which it can decide to withhold for purchases that violate its law. There are good reasons to conclude, however, that the deduction is not a subsidy but rather an appropriate allowance for measuring a taxpayer's income ${ }^{49}$ Regardless, even if viewed as a subsidy, the denial of a deduction is questionable policy. ${ }^{50}$

As noted above, even the federal government has shown ambivalence as to whether marijuana should be legalized. If a state has made legal the acquisition and use of marijuana for medical purposes, that should be sufficient to permit the consumer to deduct the expense. Moreover, it is inefficient policy for the government to increase the cost of a patient's obtaining marijuana under a doctor's recommendation to relieve a medical condition. A deduction should be allowed where the marijuana is obtained pursuant to a doctor's recommendation.

Under current law, even if the purchase of marijuana were treated as legally procured, it would not be deductible if it could be obtained without a doctor's prescription. (Currently, physicians are not allowed to prescribe — only recommend — medical marijuana, as non-FDA approved.) So, in states where marijuana can be obtained for recreational purposes, a purchase for medical purposes pursuant to a prescription would not be deductible. In effect, the purchase of marijuana would be treated like the purchase of aspirin, which is not deductible. So, removing the regulatory treatment of the purchase of marijuana as being illegally procured would not allow a deduction in those states where it can be obtained legally without a doctor's prescription.

\section{H. Hemp Industry}

Hemp is a versatile agricultural product manufactured from varieties of the cannabis plant, cultivated for industrial purposes. As hemp contains minimal THC content, it is not intoxicating. Hemp is a sturdy, durable, quick-growing, and versatile crop. Hemp stalk and fibers (bast) are high in tensile strength and are largely pest resistant. Hemp is the source of valuable industrial products. ${ }^{51}$ Over 30 nations grow significant

${ }^{47}$ Treas. Reg. § 1.213-1(e)(2).

${ }^{48}$ Rev. Rul. 97-9, 1997-1 Cum. Bull. 77.

${ }^{49}$ Kahn, Jeffrey, 2002. "Personal Deductions - An Ideal or Just Another 'Deal'?" Michigan State University-Detroit College of Law 2002 (1), 1-55.

${ }^{50}$ It is true that the medical expense deduction affects only a small percentage of the population, but because of the 10 percent floor, it is likely that many of those who take the deduction are in the lower tax brackets. That is made even more likely because the affluent are more likely to have insurance to cover their expenses. For those few who benefit from the deduction and are not affluent, the dollars saved can be precious. Medical expenses can be extremely difficult for even middle-income people who can struggle to handle them. The loss of a deduction for them can be very significant.

${ }^{51}$ An informative summary of the commercial, legal, and legislative status of hemp is Johnson, Renee, 2008. Hemp as an Agricultural Commodity. CRS Report RL32725. Congressional Research Service, Washington, DC. 
amounts of hemp for manufacturing purposes. The United States is the only industrial country in the world that banned the cultivation and sale of hemp under Schedule I of the CSA. The Hemp Farming Act, enacted in December 2018, has removed many of the restrictions on hemp cultivation, by excluding it from the CSA definition of marijuana. Nevertheless, hemp remains a highly regulated industry, with many pitfalls. For example, in determining whether hemp products remain below the legal standard of 0.3 percent concentration of THC, the United States Department of Agriculture is applying the more rigorous total THC testing requirement, which must be performed within 15 days of anticipated harvest. Likewise, there is the danger of cross-pollination among marijuana plants, leading to an increase in THC levels. Thus, it is not clear that all hemp businesses and activity will be exempt from $\S 280 \mathrm{E}$, a result that is especially absurd given the Farm Acts of 2014 and 2018 and the associated consensus that the ban on a non-intoxicating, industrial product was illogical from the beginning.

\section{Intent of Congress}

A case can be made that the application of $\S 280 \mathrm{E}$ to marijuana businesses is outdated in that it is contrary to the current view of Congress. When Congress enacted $\S 280 \mathrm{E}$, it was to strike a blow against a criminal enterprise — the illegal drug trade — that Congress deemed in 1982 to be especially harmful and pernicious. By all accounts, Congress did not anticipate that a controlled substance that it considered especially dangerous - marijuana - would be widely legalized in the United States. Congressional attitudes toward marijuana have changed drastically since 1982. The ambivalence of Congress can be seen in its annual spending amendments, which protect state legalization. On May 30, 2014, Congress passed the Rohrabacher-Farr Amendment to the Consolidated Appropriations Act, which took effect for fiscal year 2015.52 That Amendment has been renewed by Congress every year since. It prohibits the DOJ from using its funding to interfere with state laws authorizing use, distribution, possession, or cultivation of medical marijuana. On June 20,2019, the House voted overwhelmingly in favor of an amendment that would provide similar protection to states legalizing adult marijuana use (although that bill has not yet been enacted into law). With marijuana now legal to some extent in almost every state, and congressional approval of state legalization, there is a gross disconnect between the 1982 intent of $\S 280 \mathrm{E}$ and its implementation in 2019. However, despite that apparent change of viewpoint, it must be noted that Congress has so far rejected attempts to remove marijuana from Schedule I of the CSA and that does muddy the waters as to just what is the current intent of Congress. ${ }^{53}$

An argument has been made that the courts should look at the purpose of the statute rather than its literal language and that Congress did not intend to apply $\S 280 \mathrm{E}$ to

\footnotetext{
${ }^{52}$ Consolidated Appropriations Act, 2014, Pub. L. No. 113-76, 128 Stat. 5 (2014).

${ }^{53}$ None of the countless bills introduced in Congress over the last few decades have ever made it out of committee. However, 2019 saw the first bill that would reschedule marijuana, the Marijuana Opportunity, Reinvestment and Expungement Act, find approval by a congressional committee, allowing for a possible floor vote. In addition, two of the 24 votes for approval (out of 34) were by Republican members, the traditional opponents of any relaxation of the marijuana prohibition.
} 
businesses that are legally operated under state law. ${ }^{54}$ This is based on the contention that "drug trafficking" in the statutory language was meant to forbid black-market drug trafficking operations, not sales legalized by state governments, as indicated by the Committee Reports. ${ }^{55}$ This contention has been uniformly rejected by the courts. ${ }^{56}$

\section{J. State Mitigation of $\S 280 \mathrm{E}$}

Most state income tax systems track the federal tax system. For example, a state may base a taxpayer's income on his adjusted gross income for federal tax purposes, but it may make some modifications to add or subtract from that figure. Thus, unless modified by the state, a marijuana business that is legal in a state nevertheless will be prohibited from deducting its lawful expenses in determining its state income tax.$^{57}$ However, some states have taken steps to eliminate or mitigate the effect of $\S 280 \mathrm{E}$ on their income tax. ${ }^{58}$ One method is simply to provide a modification so that a marijuana business is allowed to deduct its lawful business expenses. A second, more limited approach is to allow the deduction only under certain circumstances such as when the business files a franchise tax return. A possible third approach, which no state has adopted, would be to provide a state tax credit for a portion of the additional amount of federal tax that the taxpayer paid because of the application of $\S 280 \mathrm{E}$. This latter approach would mean that the state was reimbursing the taxpayer for a portion or all of the additional tax collected by the federal government, and it is unlikely that a state would choose to do that. Moreover, a state providing tax credits to marijuana businesses might be seen as conflicting with federal legislation, the supreme law of the land, and thus preempted. ${ }^{59}$

\section{REFORMING MARIJUANA COVERAGE UNDER § $280 E$}

Sections II and III argued both that the case for banning marijuana as a dangerous narcotic has largely evaporated and that, even if appropriate, the tax treatment of marijuana businesses by $\S 280 \mathrm{E}$ is arbitrary and unjustified. There have been several proposals to prevent or mitigate the harsh and inequitable treatment imposed by that tax provision.

An obvious solution is to repeal $\S 280 \mathrm{E}$. However, that would not simply remove the restrictions on marijuana businesses but also on other drug operations. Congress has shown no inclination to do so, especially given the presence of truly dangerous narcotics in Schedules I and II.

${ }^{54}$ Vujcic, Nikola, 2016. "Section 280E of the Internal Revenue Code and Medical Marijuana Dispensaries: An Interpretation Based on Statutory Purpose." George Washington Law Review 84 (1), 259.

${ }^{55}$ See S. Rep. No. 97-494, vol. 1, at 309, reprinted in 1982 U.S.C.C.A.N. at 781, 1050.

${ }^{56}$ See Northern California Small Business Assistants, Inc. v. Commissioner, 153 TC No. 4 (2019) (reviewed by the court) and cases cited therein.

${ }^{57}$ Cleary, Patrick, 2019. "The Good, the Bad, and the Ugly: Why IRC $\S 280$ E Is Not the Industry Killer It Is Portrayed to Be." Ohio State Public Law Working Paper Series 496 (11), 8.

${ }^{58}$ See Cleary,n. 57, supra, at 9-10.

${ }^{59}$ Brilmayer, Lea, 2017. "A General Theory of Preemption: With Comments on State Decriminalization of Marijuana." Boston College Law Review 58 (3), 901-902, notes 32-36; see also Bromberg, n. 22, supra, at 225-226 (suggesting that a state providing tax credits for the purchase of medical marijuana would be preempted). 
A more limited remedy would be to leave $\S 280 \mathrm{E}$ intact and to exempt marijuana from its provisions. Numerous legislative bills have been introduced in Congress to reschedule marijuana as a controlled substance or to exempt it from the provisions of $\S 280 \mathrm{E}$, but they have received little support. ${ }^{60}$

One commentator proposed that marijuana sellers qualify themselves as "social welfare" organizations, which are exempt from federal income tax under $\S 501(\mathrm{c})(4)$ of the Internal Revenue Code ${ }^{61}$ That seems to the authors to be wholly unrealistic. One of the requirements of $\S 501(\mathrm{c})(4)$ is that the organization not be "organized for profit but operated exclusively for the promotion of social welfare...." Marijuana is a highly profitable business that is operated to make a profit. Another requirement of $\S 501$ (c) (4) is that no part of the net earnings of the entity inures to the benefit of any private shareholder or individual. The fact that a profitable business produces a product that has health benefits does not, by itself, make it an organization operated exclusively for social welfare.

A recent important tax case was brought forth by a marijuana business. ${ }^{62}$ The tax court $^{63}$ rejected a number of contentions the taxpayer made for holding $\S 280 \mathrm{E}$ inapplicable to marijuana. One of the dissents to the majority opinion rested on the fact that the denial of deductions resulted in marijuana businesses being taxed on gross income rather than on net income. The contention was that the use of the word "income" in the Sixteenth Amendment referred to net income and not to gross income. If the Sixteenth Amendment did not apply, the contention was that the tax on marijuana businesses was a direct tax that is not apportioned among the states by population and so violated Article I, Section 9, Clause 4 of the Constitution and is invalid.

It is far from clear whether the word "income" in the Sixteenth Amendment refers to net income or to gross income. The majority of the Tax Court held that the word refers to gross income. At least one dissenting judge held otherwise. Even that dissenting judge

${ }^{60}$ Professor Mikos gives several reasons why Congress is reluctant to play an active role in regulating legal marijuana, such as pushback from legalizing states. Mikos, Robert, forthcoming 2019. "The Evolving Federal Response to State Marijuana Reforms." Widener Law Review 25, 20. Available at SSRN: https:// ssrn.com/abstract=3478299. See also Rowe, Daniel, 2018. "Harmonizing Federal Tax Law and the State Legalization of Marijuana." Loyola Law Review 51 (1), 317, n. 166.

${ }^{61}$ Leff, Benjamin M., 2014. Iowa Law Review 99 (2), 523. Leff points out that a marijuana seller cannot be an Internal Revenue Code $\S 501$ (c)(3) organization because the public policy doctrine precludes charities whose purposes are illegal. See Bob Jones University v. United States, 461 U.S. 574, 591 (1983).

${ }^{62}$ Northern California Small Business Assistants, Inc. v. Commissioner, 153 T.C. No. 4 (2019) (reviewed by the court). See also Alpenglow Botanicals, LLC v. U.S., 894 F.3d 1187 (10th Cir. 2018) (rejecting argument that $\S 280 \mathrm{E}$ constitutes a criminal penalty or that the Internal Revenue Service is required to conduct a criminal investigation or prosecution to deny a deduction for "trafficking in controlled substances").

${ }^{63}$ The Tax Court is a trial court stationed in Washington, DC but holding hearings in cities throughout the United States. It consists of 19 judges. A case is usually argued before a single judge, but some cases are set for review by all of the active judges. Those are referred to as "reviewed by the court." In reviewed cases, there will be a majority opinion and there can be concurring opinions and dissents. The decisions of the Tax Court can be appealed to a Circuit Court of Appeals, and the loser of a decision of a Circuit Court can petition for review by the Supreme Court. The Tax Court is one of three courts to which a taxpayer can seek redress. Instead of going to the Tax Court, the taxpayer can sue in a U.S. District Court or in the Federal Court of Claims. Currently, the Tax Court is comprised of 19 judges, so if all 19 participate in a reviewed decision, it will require the vote of at least 10 judges to form a majority. 
recognized that Congress has great latitude in deciding which expenses are allowed to be deducted in determining net income. This issue might be raised in future litigation, but the authors doubt that the statute would be declared unconstitutional on this ground. The proposal that a tax is invalid as an apportioned direct tax has not been favored by the courts, ${ }^{64}$ but there are cases that have accepted the argument. ${ }^{65}$ The limitation on direct taxes in the Constitution was included as part of a compromise of an issue that no longer exists. The Constitution originally required that a direct tax be apportioned among the states according to population. The Sixteenth Amendment was adopted to preclude that requirement from applying to income, and the question is whether the reference to income in that Amendment is to gross income or to some version of net income. Even if it refers to net income, there is a question as to what constitutes net income. While the apportionment of a direct tax is still a constitutional requirement, the courts are likely to give a broad construction of the word "income" in the Sixteenth Amendment in order to limit the scope of the direct tax provision.

Another contention is that the denial of a deduction constitutes an excessive penalty that violates the Eighth Amendment prohibition against "cruel and unusual punishment." The opinion delivered by the majority of the Tax Court rejected the contention. The majority held that a disallowance of a deduction is not a penalty for purposes of the Eighth Amendment. The majority noted the oft-quoted statement that deductions are a matter of legislative grace and Congress can allow or deny them at will. While frequently cited, that statement is facile and should be given little to no weight. A provision that denies a deduction for legitimate business expenses only to the operators of certain businesses can be seen as a penalty for operating those ventures. However, it does not necessarily mean that it constitutes a penalty for purposes of the Eighth Amendment. The majority followed precedent in holding that it was not a penalty within the meaning of that amendment. Even if a court were to treat the denial of the deduction as a penalty, there would be a question as to whether it is sufficiently excessive such that it would violate the Eighth Amendment.

The historic case of National Federation of Independent Businesses v. Sibelius, 567 U.S. 519 (2012), has given impetus to a broader questioning of the constitutionality of $\S 280 \mathrm{E}$ as applied to marijuana. In this case, the Court ruled on the validity of the Individual Mandate provision that was part of the original version of the Affordable Care Act. The original Act imposed a penalty in the case where an individual did not have the required medical insurance coverage. The Act explicitly described the imposition as a "penalty." The Court essentially acknowledged that if the imposition was a penalty, it was invalid. Despite the explicit characterization of the imposition as a penalty in the statute, the Court held that it was not a penalty but was a tax, analogous to an excise tax. This is in line with the U.S. Supreme Court's historic reluctance to invalidate tax provisions as unconstitutional, in deference to the broad taxing power

\footnotetext{
${ }^{64}$ See, for example, Flint v. Stone Tracy Co., 220 U.S. 107 (1911).

${ }^{65}$ For example, Pollock v. Farmers Loan and Trust Co., 157 U.S. 429 (1895); Eisner v. Macomber, 252 U.S. 189 (1920).
} 
granted Congress in the Sixteenth Amendment. Nevertheless, some authors have suggested that $\S 280 \mathrm{E}$ as applied to marijuana lies outside Congress's power to tax and spend according to criteria listed in National Federation of Independent Businesses v. Sibelius for determining when a required payment constitutes a criminal penalty and not a tax. ${ }^{66}$ However, the decision in Sibelius illustrates the reluctance of courts to treat a tax provision as a penalty. If the courts were to accept this position and treat the denial of a deduction as a penalty, it would set a precedent that could impact on the constitutionality of other disallowances of deductions and possibly even on the granting of a deduction or credit to some businesses and not to others. That would have far-reaching consequences that could spur extensive litigation. A court is likely to hesitate before embarking on that path. Indeed, that may well be the reason that courts, to date, have uniformly rejected a contention that a tax provision should be treated as a penalty.

Additionally, it is possible that an unincorporated marijuana business may take advantage of a new provision in the 2017 Tax Cuts and Jobs Act that allows some sole proprietorships and pass-through entities to deduct up to 20 percent of their qualified business income ( $§ 199 \mathrm{~A})$. This would lower the top federal individual marginal tax rate from 37 percent to 29.6 percent. ${ }^{67}$ While there are a number of ineligible businesses precluded from using this qualified business deduction, marijuana businesses are not so listed.$^{68}$ This deduction is not available to corporations, ${ }^{69}$ and it is likely that most marijuana businesses are incorporated. Even if not incorporated, for example, operating as an LLC, there are serious issues as to whether this deduction will be available to a marijuana business.

Section 280E denies a deduction for expenses that are paid or incurred. The deduction in 199A is determined as a percentage of qualified business income and so is not a deduction for an amount paid or incurred (i.e., it is not a deduction for an expense). The literal terms of $280 \mathrm{E}$ would seem not to apply. However, 199A has a ceiling that limits the amount of the deduction to a percentage of wages paid by the organization. ${ }^{70}$

\footnotetext{
${ }^{66}$ Pack, Julie, 2017. "Powerless to Penalize: Why Congress Lacks the Power to Penalize Marijuana Businesses through $\S 280 \mathrm{E}$ of the Internal Revenue Code.” Arizona Law Review 59 (4), 1081. See, for example, Department of Revenue of Montana v. Kurth Ranch, 511 U.S. 767, 768 (1994), where the U.S. Supreme Court held that a purported excise tax on marijuana possession was in a criminal penalty for possession of marijuana, thus violating the Fifth Amendment prohibition against successive punishments for the same offense. In reaching this conclusion, the Court relied on the fact that the assessment was disproportionate to the value of the marijuana (more than eight times the drug's market value), it was "conditioned on the commission of a crime," and its evident purpose was to deter possession of marijuana.

${ }^{67}$ Rowe, Daniel, 2019. "Cannabis Businesses and Passthrough Deduction Availability." Tax Notes, https:// papers.ssrn.com/sol3/papers.cfm?abstract_id=3389164 for one discussion of this issue.

${ }^{68}$ Aspir, Benjamin Aspir, 2019. "The Cannabis Industry and the Qualified Business Deduction § 199." EisnerAmper, New York, NY, https://www.eisneramper.com/cannabis-qualified-business-deduction-199a-0219/; Cleary, Patrick, 2019. "The Good, the Bad, and the Ugly: Why IRC $\S 280$ E Is Not the Industry Killer It Is Portrayed To Be.” Ohio State Public Law Working Paper Series, 496 (11), 13.

${ }^{69} \S 199 \mathrm{~A}(\mathrm{a})$.

${ }^{70} \S 199 \mathrm{~A}(\mathrm{~b})(2)$.
} 
Since that ceiling is part of the formula for calculating the amount of the deduction, it raises the question of whether the deduction can be held to be given for an amount paid. $^{71}$ The fact that an amount paid is part of the formula for calculating the deduction might make the provision subject to $\S 280 \mathrm{E}$ even if the statute is read literally. While not addressing this issue, the Tax Court in the Northern California case stated that the statute applies to all deductions attributable to a marijuana business.

Several commentators suggest that a marijuana-based Real Estate Investment Trust (REIT) may be able to use $\S 199$ A to deduct up to 20 percent of its qualified dividends and publicly traded partnership income. ${ }^{72}$ It is not possible for a REIT to qualify to use $\S 199 \mathrm{~A}$. One requirement for being a REIT is that the organization be one that would be taxable as a domestic corporation if the REIT provision did not apply. ${ }^{73} \mathrm{~A}$ REIT is taxed at corporate tax rates except that it has special tax treatment including some pass-through elements. In this respect, it is similar to an S corporation. More importantly, Treas. Reg. section 301.7701-3(c)(v)(B) provides that an entity that elects to be treated as a REIT is treated as having elected to be treated as an association; in defining what constitutes a corporation for tax purposes, Treas. Reg. section 301.7701-2(b)(2) designates that an association is classified as a "corporation."

In any event, there would seem to be very few marijuana businesses, if any, that could qualify as a REIT. Among the requirements to be a REIT is that 75 percent of its assets have to be in real estate, cash, cash items, and government securities. ${ }^{74}$ Also, 75 percent of its gross income has to come from rent or mortgage interest plus a few other items that do not include income from the sale of marijuana. ${ }^{75}$ It must have at least 100 owners. ${ }^{76}$ At least 95 percent of its gross income must be derived from income from real property or personalty held incident to realty, dividends, and interest. ${ }^{77}$ Even if the marijuana business qualified as a REIT subsidiary, it would still have the problem that the REIT is a corporation for tax purposes.

\section{CONCLUSION}

Much medical evidence indicates that marijuana should not be classified as a dangerous narcotic; consequently, the differential tax treatment of marijuana businesses whereby these firms are taxed on their gross income, rather than net income (as are most other comparable businesses), is arbitrary and unjustified. While there is certainly a risk of harmful effects - arguably no more than those of many other drugs that are permitted

\footnotetext{
${ }^{71}$ Northern California Small Business Associates, Inc. v. Commissioner, n. 56, supra.

72 Guttery, Randall S., and Stephen L. Poe, 2018. "Using a Cannabis Real Estate Investment Trust to Capitalize a Marijuana Business.” Journal of Real Estate Portfolio Management 24 (2), 201-206.

${ }^{73} \S 856(\mathrm{a})(3)$.

${ }^{74} \S 856(\mathrm{c})(4)$.

${ }^{75} \S 856(\mathrm{c})(3)$.

${ }^{76} \S 856(\mathrm{a})(5)$.

$77 \S 856(\mathrm{c})(2)$.
} 
by the FDA - there is a growing body of research that emphasizes the positive aspects of the drug and how it can provide relief for symptoms of a number of illnesses. As such, a majority of states have legalized the use of marijuana for medicinal purposes. Given this and that a sizeable majority of the public favor legalizing marijuana, there seems little reason for there to be a federally mandated prohibition of use of marijuana under all circumstances. Without the specter of federal enforcement of this ban, the states could better serve as laboratories to see the consequences of legalization of marijuana for medicinal purposes.

The question of whether recreational use of marijuana should be permitted is more contested. So far, only 11 states have legalized its use for such purposes. Maintaining the harsh federal strictures against adult recreational use is not likely to cause a significant reduction of its use. In addition to criminalizing the use of marijuana, the federal government has used the tax law to penalize businesses that sell marijuana. Section $280 \mathrm{E}$ disallows a deduction for the legal operating expenses of a marijuana business even when the business is legal under state law. This treats drug businesses more harshly than even illegal businesses that are permitted to deduct their legal operating expenses. Even if it is proper to single out drug businesses for special punitive treatment, the device chosen in $\S 280 \mathrm{E}$ is arbitrary in that the size of the penalty bears no relationship to the seriousness of the events. To the contrary, the size of the penalty rests on factors that have nothing to do with the seriousness of the matter. Moreover, there is no good reason to counter the decision of a state to permit the use of marijuana by imposing a large penalty on those businesses through the tax law.

In Section III of this article, we examined several possible rationales for the denial of a deduction and found that they did not bear scrutiny, and in Section IV, we examined several proposals to mitigate the adverse impact of $\S 280 \mathrm{E}$ on marijuana and similarly found them wanting. Where does that leave us? It is clear that the seemingly intractable conflict between the federal tax policy toward marijuana and the acceptance of its use by many states is counter to the ideals of federalism - indeed, a recent court case framed the issue as the "largest federalism dispute this country has seen since the Civil War."78 Leaving aside difficult questions of whether contrary state laws as to marijuana are preempted by the federal prohibition, as the supreme law of the land ${ }^{79}$ it is difficult to understand why the federal government would impose a view on the states that marijuana has "no medical use" and thereby interfere with the decisions of a majority of states to permit and regulate its use. Congress has adhered to the view adopted in the 1970 CSA and resisted efforts to make a significant change in the CSA. Yet, Congress

\footnotetext{
${ }^{78}$ Brief of the Petitioner in Alpenglow Botanicals, LLC v. U.S. in Support for a Request for Writ of Certiorari from the Tenth Circuit (Feb. 21, 2019) at 3.

${ }^{79}$ For example, Chemerinsky, Erwin, Jolene Forman, Allen Hopper, and Sam Kamin, 2015. "Cooperative Federalism and Marijuana Regulation. " UCLA Law Review 62 (1), 100-112; Osbeck, Mark, and Howard Bromberg, 2017. Marijuana Law in a Nutshell, 141-163. West Academic Publishing, St. Paul, MN (discussing federalism and preemption).
} 
itself has shown doubts about that view when, for the past six years, it has passed legislation preventing the DOJ from enforcing the marijuana prohibition in Schedule I of the CSA. It is peculiar to say the least to prevent the enforcement of the prohibition while continuing to penalize marijuana businesses by denying them tax deductions and credits. Ultimately, the problems imposed on marijuana businesses by $\S 280 \mathrm{E}$ will be resolved only when the conflicts in the treatment of marijuana in this country are resolved.

\section{DISCLOSURES}

The authors have no financial arrangements that might give rise to conflicts of interest with respect to the research reported in this paper. 